\title{
Using content validity measures to evaluate the Biosystems Engineering Program at the University of Manitoba
}

\author{
Jillian Seniuk Cicek ${ }^{1, *}$, Robert Renaud ${ }^{1,2}$, and Danny Mann ${ }^{3}$ \\ ${ }^{I}$ Centre for Professional Practice and Engineering Education, University of Manitoba, Winnipeg, MB Canada \\ ${ }^{2}$ Educational Administration, Foundations and Psychology, Faculty of Education, University of Manitoba, Winnipeg, MB \\ Canada \\ ${ }^{3}$ Department of Biosystems Engineering, University of Manitoba, Winnipeg, MB Canada \\ ${ }^{*}$ Corresponding Author: Jillian.SeniukCicek@umanitoba.ca
}

\begin{abstract}
An exploratory case study was designed to determine the relative importance of the Canadian Engineering Accreditation Board (CEAB) graduate attributes as perceived by University of Manitoba engineering stakeholders. Findings were used to examine the content validity of the Biosystems Engineering program. The overarching objective was to explore how graduate attribute emphasis in engineering programs reflect graduate attribute importance reported by key stakeholders. Problem Analysis, Investigation, Design, Communication Skills, Impact of Engineering on Society \& the Environment, and Use of Engineering Tools had similar expected (mean relative importance) and observed (content and assessment program coverage) data percentages. The gap was wider for other graduate attributes, with the most surprising being Knowledge Base. Overall, the pattern of results suggests that various professional attributes (e.g., Professionalism, Ethics \& Equity, and Lifelong Learning) should be more prominent in content and assessments within an engineering program. Recommendations to improve methods to assess content validity in engineering programs are discussed.
\end{abstract}

\section{RÉSUMÉ}

Une étude de cas exploratoire a été conçue pour déterminer l'importance relative des qualités requises des diplômés du Bureau canadien d'accréditation des programmes d'ingénierie (BCAPI) tels que perçus par les intervenants en génie de l'Université du Manitoba. Les résultats ont été utilisés pour examiner la validité du contenu du programme de génie des biosystèmes. L'objectif principal était d'explorer comment l'importance des qualités requises des diplômés dans les programmes d'ingénierie reflète l'importance de ces qualités signalée par les principales parties prenantes. L'analyse des problèmes, la recherche, la conception, les compétences en communication, l'impact de l'ingénierie sur la société et l'environnement ainsi que l'utilisation des outils d'ingénierie présentaient des pourcentages de données attendus (importance relative moyenne) et observés (contenu et couverture $\mathrm{du}$ programme d'évaluation) similaires. L'écart était plus important pour les autres qualités requises des diplômés, le plus surprenant étant la base de connaissances. Dans l'ensemble, la tendance des résultats suggère que divers qualités professionnels (p. ex., le professionnalisme, l'éthique et l'équité, et l'apprentissage continu) devraient occuper une place plus importante dans le contenu et les évaluations d'un programme de génie. Les recommandations visant à améliorer les méthodes d'évaluation de la validité du contenu des programmes d'ingénierie sont discutées.

\section{KEYWORDS}

Program evaluation, CEAB graduate attributes, biosystems engineering, content validity, relative importance, exploratory case study.

\section{MOTS CLÉS}

évaluation de programme, qualités requises des diplômés du BCAPI, génie des biosystèmes, validité du contenu, importance relative, étude de cas exploratoire.

\section{CITATION}

Seniuk Cicek, J., R. Renaud and D. Mann. 2020. Using content validity measures to evaluate the Biosystems Engineering Program at the University of Manitoba. Canadian Biosystems Engineering/Le génie des biosystèmes au Canada 62: 9.1-9.16. https://doi.org/10.7451/CBE.2020.62.9.1 


\section{INTRODUCTION}

There is global agreement on the critical role of engineering competencies for engineers of the 21 st century. This is demonstrated by engineering accreditation boards around the world that have moved away from solely quality assurance models focused on documenting inputs in engineering programs to outcomes-based models concentrated on assessing students' competencies, improving their learning, and supporting a cycle of continual program improvement (Almarshoud 2011; Oliver 2013; Prados et al. 2005). Accredited engineering programs are required to demonstrate that their programs are designed to teach students the knowledge, skills and values identified in defined technical and non-technical (i.e., 'professional') engineering competencies, and their graduating engineering students are competent in these areas (Davis et al. 2002; Olds et al. 2005).

Research shows that there is a growing awareness of the value of outcomes-based pedagogical practices, not only for enhancing student learning (Heinricher et al. 2002), but also for enriching program quality (Prados et al. 2005). Outcomes-based education is a process that continually focuses on student learning and demands institutions to be accountable to the evidence of that learning (Driscoll and Wood 2007); outcomes-based systems are designed to isolate, gather, examine, and report data for evidence of student learning. Outcomes-based pedagogy is meant to be a dynamic process: a continuous cycle of assessment and program improvement (Davis et al. 2002; Dew et al. 2011; Fredericks Volkwein et al. 2004; McCahan et al. 2011; Moskal 2008). Outcomes are the parts of a student's development that an institution endeavors to impact through their educational programs and procedures (Soundarajan 2002). They describe what students are expected to know and do by the time of graduation. The outcomes of a student's education are affected by who they are when they come into an institution, what they experience both in their courses and as a result of the program, and how all of those experiences and influences work together to form their understanding of, and attitudes towards learning overall, and in particular, towards their field or profession (Rogers 2000).

Engineering learning outcomes were first identified in 1996 by the Accreditation Board for Engineering and Technology (ABET), the body responsible for accrediting American (and other) college and university programs in applied science, computing, engineering, and engineering technology. They were developed in response to a number of reports and movements to disrupt the engineering curricula and make room for reform (Borrego and Bernhard 2011; Oliver 2013; NEERC 2006). They represented the competencies critical for preparing engineering graduates for professional practice in a multifaceted and changeable world (Passow 2012). In 2013, they were adopted by the signatories of the Washington Accord as a reference point to measure 'substantial equivalence' of individual country's accreditation requirements (International Engineering
Alliance 2014). Although these engineering competencies are identified, educators are responsible for defining them, as explained by Passow and Passow $(2017,475)$ : 'Under Washington Accord or ABET accreditation requirements, faculty must envision, collectively articulate, and prioritize the competencies that students should gain from their educational program to prepare for life and myriad career paths' (emphasis ours).

These requirements are now consistent with engineering education in Canada. Previous to the adoption of outcomes-based assessment, Canadian engineering schools traditionally offered courses designed using inputsbased systems (Wolf and Stiver 2011) and evaluated their programs by documenting these inputs. This typically included tracking time spent in a lab, classroom and tutorial contact hours, and personnel, such as number of sessional instructors, instructors with $\mathrm{PhDs}$, and professors registered as professional engineers. Among other input data, programs were (and still are) required to measure Accreditation Units (AUs), and record the hours devoted to engineering fundamentals such as mathematics, natural sciences, engineering science, engineering design, and complementary studies. In 2009, the Canadian Engineering Accreditation Board (CEAB) initiated an outcomes-based approach for engineering curriculum development and assessment (Frank et al. 2011; Frank and Fostaty-Young 2011; Wolf and Stiver 2011). Since 2014, Canadian institutions seeking CEAB accreditation are responsible for developing systematic and valid curricula, and outcomesbased pedagogical strategies and assessment tools that are constructively aligned with their educational objectives and teaching methodologies (McGourty et al. 1999; Biggs 1999; Biggs 2013). They must create and implement an assessment protocol to evaluate students' attainment of the program's educational objectives and the accreditation outcomes mandated, and these results must ideally be used to incur program improvement (Davis et al. 2006; Popp et al. 2012; Rogers 2000; Soundarajan 2002).

The outcomes that are required of Canadian engineering graduates are identified by $12 \mathrm{CEAB}$ graduate attributes and can be linked to the ABET Criterion 3 Student Outcomes and the Washington Accord Graduate attributes. They consist of what has been controversially defined as the 'technical' engineering competencies (graduate attributes 1 - 5), and the 'professional' or non-technical competencies (graduate attributes 6-12) (for a discussion on engineering technical and professional skills, see Shuman et al. 2005). They are:

1. A knowledge base for engineering

2. Problem analysis

3. Investigation

4. Use of engineering tools

5. Design

6. Individual \& teamwork

7. Communication skills

8. Professionalism

9. Impact of engineering on society $\&$ the environment 
10. Ethics \& equity

11. Economics \& project management

12. Lifelong learning

To achieve accreditation, Canadian institutions, like institutions accredited by ABET (Felder and Brent 2003), are faced with the challenge of evaluating their programs and improving them to satisfy $\mathrm{CEAB}$ requirements. This is difficult, as CEAB has provided a list of graduate attributes, but no baseline, and no way to 'calibrate' improvements (Pons 2016, 535). The relative importance of the CEAB graduate attributes is not given, which is critical when improving existing curricula to demonstrate graduate attribute competencies.

\section{LITERATURE REVIEW}

Research conducted to ascertain how to prioritize engineering competencies is found in Australia, New Zealand, the UK, Europe, and the USA. Nguyen (1998) surveyed Australian engineering students, academics, and industry to determine their views on the most essential competencies for the 'modern' engineering (p. 65). Participants ranked a group of 7 engineering generic skills and attributes each with several sub-groups of specialized skills on a hundred-point scale. Findings were divided into three groups: essential, desirable, and advantageous, determined by the rating overlaps between the three stakeholder groups. Fundamental engineering knowledge, including practical and technical skills, was found to be most essential, in addition to understanding the impact of engineering on the environment. Nguyen (1998) argued that due to the 'remarkable difference in rankings between industry and the other two groups... engineering education is producing a different engineer to that desired by industry, and that engineering education is perhaps failing to meet market demand' (p. 67, p. 69).

Male, Bush and Chapman (Male 2010; Male et al. 2010, 2011a, 2011b) surveyed 300 Australian engineers to confirm findings from international studies on competency deficiencies in project management skills, communication and leadership and practical application and business skills in the Australian context. Participants rated 64 competencies derived from the literature for importance to their jobs and gave perceptions of competency deficiencies via open ended questions. The authors used the importance ratings to devise a competency model for identifying generic competencies required by engineering students. Communication, teamwork, self-management, professionalism and ingenuity had the highest competency factor scores (Male 2010); practical engineering, engineering business competencies, communication skills, self-management and appropriate attitude, problem solving, and teamwork had dominant competency deficiencies (Male et al. 2010). Other Australian research on engineering competencies using survey methods confirmed deficits in emotional intelligence (Scott and Yates 2002); accountability, teamwork, communication, interpersonal skills and skills to advocate and influence (Bons and McLay 2003); communication and graduate business skills (Ashman et al. 2008); and communication, problem solving, time-management, teamwork, application of knowledge in the workplace, ability to cope with stress, and capacity to learn (Nair et al. 2009). Overall, many of the deficiencies were found in the professional skills.

Pons (2016) conducted a large-scale survey of practicing engineers in New Zealand to determine what engineering management topics should be taught to students. Thirty-three professional skills topics were provided based on the Washington Accord graduate attributes and the literature, and participants were simply asked to select all that apply (note that technical competencies were not included). The relative importance of engineering management topics was determined by the frequency they were chosen by participants. Communication and project management were selected most frequently.

Bodmer et al., as cited in Male et al. (2010), surveyed 1372 engineers in Europe and the USA for competency ratings of importance and graduate performance, finding gaps in communication, leadership and social skills. Robinson et al. (2005) conducted a mixed methods study of one company in the UK to identify the most important future competencies for Design engineers. Participants rated the importance of 49 competencies based on their current job, and their perception of their job 10 years into the future. Findings from qualitative interviews supported the development of the questionnaire, as well as identifying future top-rated competencies using critical incident questioning following the questionnaire. Criticality ratings for each competency was based on the proportion of interviewees who indicated a competency during the post interviews. The future competency profile derived were 42 competencies divided into six groups in order of importance: personal attributes, project management, cognitive strategies, cognitive abilities, technical ability, and communication (Robinson et al. 2005).

In the USA, Passow (2012) found engineering alumni ranked teamwork and communication as two out of four top competencies in their professional practice. Data analysis and problem solving were the other. Passow and Passow (2017) conducted a comprehensive, global, systematic literature review on engineering competencies in engineering practice to 'answer the practical question of curriculum design: What competencies should undergraduate engineering programs emphasize?' (p. 476), by 'Defining the nature of engineering work and the generic competencies required in engineering practice' (p. 504). They identified 16 engineering competencies important to engineering practice, which divided into four clusters. They compared these to, and expanded them from, the Washington Accord competencies. Problem solving, communication and teamwork were the top competencies.

Overall, top competencies and competency deficiencies in these studies were largely found in the engineering 'professional' skills. As well, all of the studies discussed focus on 'expected' or 'desired' performance, but 
none of them examine 'observed' performance in engineering education programs. In Canada, while numerous publications on the CEAB graduate attributes have explored important questions pertaining to classroom assessment (Sullivan and Brennan 2018), there is an absence of research on how to prioritize the CEAB graduate attributes, and an absence of research that explores, from a content validity perspective, the basic question of how much each graduate attribute should be covered and assessed within engineering programs. Canadian engineering faculty need to have a clear understanding of how the graduate attributes manifest for Engineers-inTraining (EITs) at the beginning of their career, as this is the point at which newly graduated engineering students will first employ the graduate attributes in practice. The relative importance of each of the CEAB graduate attributes to the practice of EITs will apprise engineering educators how to emphasize the graduate attributes in engineering curricula. This knowledge can then be used to evaluate and improve engineering programs. This, 'process-oriented' question can be answered in two basic steps: (1) identifying the expected level of importance of each CEAB graduate attribute, and (2) comparing, for each graduate attribute, the expected level of importance to what is observed in the program. While tools reflecting the expected level of relative importance have been developed in other disciplines such as Medicine (Stutsky et al. 2012) and Nursing (Renaud 2019) in Canada, it appears that a comparable tool has not been developed in Engineering.

\section{PURPOSE}

This engineering education research article reports on the second phase of an exploratory case study conducted to explore how the emphasis on graduate attributes in the engineering programs at the University of Manitoba reflect their reported importance by key engineering stakeholders for an Engineer-in-Training at the beginning of their professional practice. The purpose of the study was to (1) to develop a criterion measure of relative importance for each of the graduate attributes, and (2) to assess the content validity of the Biosystems Engineering program by comparing the expected importance to the observed levels of content coverage and assessment, for each CEAB graduate attribute. The study was executed in two phases. The first phase was designed in part to determine the relative importance of the CEAB graduate attributes for an EIT at the beginning of their career as perceived across three University of Manitoba engineering stakeholder groups: students, faculty, and Manitoba industry members belonging to the group affiliated with the Price Faculty of Engineering, Friends of Engineering, an external organization comprised of senior-level executives, managers, team leaders and engineering champions who support engineering education and strong relations between Manitoba industry and the Price Faculty of Engineering (see https://friendsofengineering.ca/about-us/). The second phase was designed to evaluate the content validity of the Biosystems Engineering program as measured by the mean relative importance of the $\mathrm{CEAB}$ graduate attributes determined by engineering stakeholders. Findings, such as the differences in relative importance ratings between stakeholders, are reported on in other work (see Seniuk Cicek and Renaud 2019). This paper presents the findings from phase 2 of the study, the content validity evaluation of the Biosystems Engineering program, expanded here from Seniuk Cicek et al. (2018). This phase was guided by the research question: In the Biosystems Engineering program, how do the percentages of course content coverage and course assessments of the CEAB graduate attributes compare with their perceived relative importance by all engineering stakeholders? The purpose of this study is to inform the improvement and development of authentic outcomes-based engineering curricula informed by engineering practice.

\section{METHODS}

An index of relative importance was compared to the total percentages of core course content coverage and course assessments of the $12 \mathrm{CEAB}$ graduate attributes in the Biosystems Engineering program to evaluate the content validity of the program.

\section{Department of Biosystems Engineering, University of Manitoba}

The Department of Biosystems Engineering is one of five engineering programs at the University of Manitoba, a large research university in Winnipeg, Canada, and is an academic unit in the Faculty of Agricultural \& Food Sciences. It offers both undergraduate and graduate level programs, supporting approximately 160 undergraduate students and 80 graduate students each year. The undergraduate program is housed within and accredited through the Price Faculty of Engineering. The Biosystems undergraduate program comprises 45 required courses, some of which are taught within the department, and others outside, within the Faculties of Engineering, Arts or Science (see Appendix A for the Biosystems 5-year model). Thirtyfive of the courses are considered core courses, with the remaining 10 courses fitting into four categories of electives (i.e., two science electives, three Biosystems design electives, three complementary studies electives, and two free electives). In this study, the 35 core courses were evaluated to determine the content validity of the Biosystems Engineering program.

\section{Index of relative importance}

A closed-ended rating survey was designed to determine the relative importance of the $\mathrm{CEAB}$ graduate attributes as perceived by engineering stakeholders at the University of Manitoba (i.e., students, faculty, and Manitoba industry members in partnership with the Price Faculty of Engineering through the organization, Friends of Engineering). Table 1 shows the distribution of stakeholder participants by engineering area.

Biosystems Engineering was represented by $13.2 \%$ of study participants. Overall, participation rates were reflective of student representation in the Biosystems 
Table 1. Phase 1 stakeholder participation by engineering department.

\begin{tabular}{lrcrrrrrr}
\hline Stakeholder & Population & $\begin{array}{c}\text { Participation } \\
\text { All Areas }\end{array}$ & BIOE & CIVL & COMP & ELE & MECH & EPP \\
\hline Student & 235 & $125(53.2 \%)$ & 12 & 50 & 16 & 31 & 16 & 0 \\
Faculty & 91 & $46(50.5 \%)$ & 11 & 7 & 3 & 7 & 14 & 4 \\
Industry & 70 & $48(68.6 \%)$ & 6 & 15 & 5 & 10 & 11 & 1 \\
Total & 396 & 219 & 29 & 72 & 24 & 48 & 41 & 5 \\
Total \% & 100 & 55.3 & 13.2 & 32.9 & 11.0 & 21.9 & 18.7 & 2.3
\end{tabular}

Note: BIOE (Biosystems); CIVL (Civil); COMP (Computer); ELE (Electrical); MECH (Mechanical); EPP (Centre for Engineering Professional Practice and Engineering Education).

Engineering program with less than $1 \%$ difference between student capacity and Phase 1 participation rates. Eleven out of 14 Biosystems faculty participated, at a $78.6 \%$ rate. Within the Biosystems Engineering program, while the number of student and industry participants could have been greater, these two sub-groups were of sufficient size to provide a fairly stable estimate of the mean importance ratings. It is unlikely that ratings from additional participants would result in a notable change for the mean importance for any of the attributes.

Participants were given a list of the 12 graduate attributes and the CEAB definition for each attribute (see Appendix B for CEAB Graduate Attributes Rating Form). They rated each graduate attribute along a 5-point Likert scale for frequency (Table 2), and a 5-point Likert scale for criticality (Table 3 ).

The relative importance was calculated as follows: Data were collected on the perceived frequency of a graduate attribute for an EIT in engineering practice, i.e., how often an EIT at the beginning of his/her career will perform a task that clearly requires a graduate attribute (Table 2), and the perceived criticality of a graduate attribute, i.e., the potential effect on workplace performance for an EIT at the beginning of his/her career if he/she does not have a sufficient level of competency for this graduate attribute (Table 3) (see Seniuk Cicek et al. (2017a) for a more detailed account of survey development).

The mean perceived absolute importance (I) of each graduate attribute (attribute $i$ ) for each stakeholder was calculated by multiplying the frequency (F) and the criticality (C) of attribute $i$, as represented in the formula $\mathrm{I}_{\mathrm{i}}=\mathrm{F}_{\mathrm{i}} \mathrm{C}_{\mathrm{i}}$ (Stutsky et al. 2012). The mean percentage of each graduate attribute's absolute importance to the total absolute importance of all graduate attributes was computed to develop an index of relative importance. As the relative importance of each graduate attribute was fairly similar across each of the three stakeholder groups, the perceptions of all engineering stakeholders combined was used as a criterion measure for assessing the content validity of the Biosystems Engineering program.

\section{Content validity evaluation}

The second purpose of this study was to evaluate the measure of content validity of the Biosystems Engineering program in order to inform the improvement and development of authentic outcomes-based engineering curricula. Ro et al. (2015) describe content validity within the domain of validity:

"Evidence based on test content refers to the extent to which a scale's items, in the aggregate, constitute a representative sample of the topic's content domain. Do the items reflect what has been defined as "contextual competence" (Suen, 2008; Trochim, 2006)? To answer the question, content experts are consulted and their professional judgment is taken to reflect the degree of what was traditionally called "content validity." (p. 37-38)

Content validity shows whether or not the content within the instrument is demonstrative of the intended concept to

Table 2. Frequency scale.

\begin{tabular}{lllll}
\hline 1 & 2 & 3 & 4 & 5 \\
\hline Rarely & Sometimes & Regularly & Quite often & All the time \\
$1-2$ times/year & $1-2$ times/month & $1-2$ times/week & once per day & several times/day \\
\hline
\end{tabular}

Table 3. Criticality scale.

\begin{tabular}{|c|c|c|c|c|}
\hline 1 & 2 & 3 & 4 & 5 \\
\hline $\begin{array}{l}\text { No consequence } \\
\text { (Nothing to either } \\
\text { correct or repeat) }\end{array}$ & $\begin{array}{l}\text { Minor consequence } \\
\text { (Little or no harm, } \\
\text { damage or } \\
\text { inconvenience, can } \\
\text { correct without help) }\end{array}$ & $\begin{array}{l}\text { Moderate consequence } \\
\text { (Notable harm, damage } \\
\text { or inconvenience, may } \\
\text { need help to correct) }\end{array}$ & $\begin{array}{l}\text { Major consequence } \\
\text { (Serious harm, damage } \\
\text { or disruption, likely need } \\
\text { help to correct) }\end{array}$ & $\begin{array}{l}\text { Extreme consequence } \\
\text { (Irreversible or } \\
\text { irreparable harm or } \\
\text { damage, resulting in } \\
\text { injuries, death or } \\
\text { destruction of } \\
\text { material/natural world, } \\
\text { and/or reputation) }\end{array}$ \\
\hline
\end{tabular}


be measured (Gliner et al. 2009, p. 166). In this research, the content validity of an engineering curriculum is being measured by comparing the overall percentage that each CEAB graduate attribute is taught and assessed in the core Biosystems Engineering program to the mean relative importance of the graduate attributes as determined by all engineering stakeholders in this case. The assumption is that the more relatively important a graduate attribute is, the more 'representativeness' it should have in the curriculum, thereby establishing a measure of content relevance (Jonsson and Svingby 2007, p. 136).

Content coverage and assessments for the 12 CEAB graduate attributes in the Biosystems Engineering program

Faculty teaching core courses in the Biosystems Engineering program were asked to identify, in their judgment, what percentage of time they spend teaching and what percentage of time they spend assessing the applicable CEAB graduate attributes in their course. For this purpose, the Teaching Faculty Course Content Questionnaire was developed (see Appendix C). Questionnaires were prepared individually for each course based on the targeted CEAB graduate attributes derived from accreditation documents and the previous work done to validate and implement a set of graduate attribute rubrics in the Biosystems Engineering curriculum (see Seniuk Cicek et al. 2017b). Faculty were asked to confirm or correct the graduate attributes identified for their course at the outset of the questionnaire, and then answer the subsequent questions based on the confirmed graduate attributes. Prior to collecting these data, the Head and Associate Head of the Department of Biosystems Engineering reviewed pilot versions of the questionnaire and made minor revisions to the instructions to improve clarity, and to ensure it could be completed within the expected brief length of time.

There are 35 core courses in the Biosystems program. All faculty members teaching courses in the Department of Biosystems Engineering $(n=14)$ as well as faculty from other departments in the Price Faculty of Engineering who taught courses required by the Biosystems Engineering program $(\mathrm{n}=7)$ filled out the Teaching Faculty Course Content Questionnaire during the Fall 2017 term. The data collected from the questionnaire delineated both the percentage of time spent teaching and assessing each of the graduate attributes based on faculty members' professional judgment (Ro et al. 2015).

For the courses taught outside the Department of Biosystems Engineering $(n=14)$ - courses offered either within the Price Faculty of Engineering or in the Faculties of Arts or Sciences - where faculty did not fill out the questionnaire, the first author used Price Faculty of Engineering accreditation documents to ascertain which CEAB graduate attributes were taught and assessed in each course and estimated the percentage of time spent on each. It was found that the percentage of assessments for each graduate attribute was delineated in these documents; however, the percentage of time spent teaching these graduate attributes was not. If the percentage of time spent teaching each of the applicable graduate attributes could not be clearly determined from additional documentation (i.e., course syllabi), the first author assumed that the percentage of time spent teaching the graduate attributes was equal to the percentage of assessments for each.

The total percentages of core course content coverage and course assessments for each of the $12 \mathrm{CEAB}$ graduate attributes in the Biosystems Engineering program were compared with the mean perceived relative importance findings of the $\mathrm{CEAB}$ graduate attributes for all engineering stakeholders to evaluate the content validity of the Biosystems Engineering program.

\section{Research Ethics and University Approval}

Ethics approval for the study was granted through the Education and Nursing Research Ethics Board (ENREB) at the University of Manitoba. Additionally, permission to survey the university's faculty and students was approved by the Office of Institutional Analysis, and by the Dean of Engineering. To help minimize possible forms of bias, participation for all stakeholders was optional and confidential, and recruitment was sought following all ENREB and University of Manitoba regulations.

\section{FINDINGS}

Table 4 illustrates, for each of the 35 core courses in the Biosystems Engineering program, the percentage of content coverage and course assessments of each applicable graduate attribute based on the professional judgement of the course instructors, expert faculty, and accreditation documents. The bottom rows demonstrate the total percentage of content coverage and total percentage of course assessments for each graduate attribute for the whole program. Total percentages are the total sum that each graduate attribute was taught and assessed for each course, multiplied by 100 and divided by 3500 (i.e., 35 courses multiplied by $100 \%$ each).

The total core course content taught in the BIOE program comprises just under 50\% Knowledge Base for Engineering, 13\% Problem Analysis, just over 10\% Design and $7 \%$ Communication Skills, approximately $4.5 \%$ each of Use of Engineering Tools and Investigation, 4\% Impact of Engineering on Society \& the Environment, and just over $1 \%$ each of Individual \& Teamwork, Professionalism, Ethics \& Equity, and Economics \& Project Management. There are very similar percentages for the core course content taught and assessed for each CEAB graduate attribute in the Biosystems Engineering program, with the largest discrepancy being 1.5\% (for Problem Analysis, which is assessed insignificantly more than it is taught).

With one exception, the ranked order of the CEAB graduate attributes based on the course content coverage and course assessments in the Biosystems Engineering program places the most emphasis on the $\mathrm{CEAB}$ graduate attribute 'technical' skills (i.e., Knowledge Base, Problem Analysis, Investigation, Design, and Use of Engineering Tools), and less emphasis on the 'professional' skills (i.e., Individual \& 
Teamwork, Communication Skills, Professionalism, Impact of Engineering on Society \& the Environment, Ethics \& Equity, Economics \& Project Management, and Lifelong Learning), reflecting importance in line with the numerical order of the CEAB graduate attributes. The exceptions include the relatively larger emphasis in the program on professional competency, Communication Skills, which is emphasized more than the technical competencies, Use of Engineering Tools and Investigation.
To evaluate the content validity of the Biosystems Engineering program, the course content and assessment data were compared to the mean relative importance of the graduate attributes data based on the perceptions of all stakeholders (students, faculty and industry) who responded to the relative importance questionnaire $(n=207)$. Findings are shown in Table 5.

In Table 5, we see attributes in which the expected levels (column 2, the relative importance of all stakeholders) and observed levels (columns $3 \& 4$, the

Table 4. Percentage of course content coverage and course assessments $(x, x)$ for CEAB graduate attributes in Biosystems Engineering core program ( $N=35$ courses).

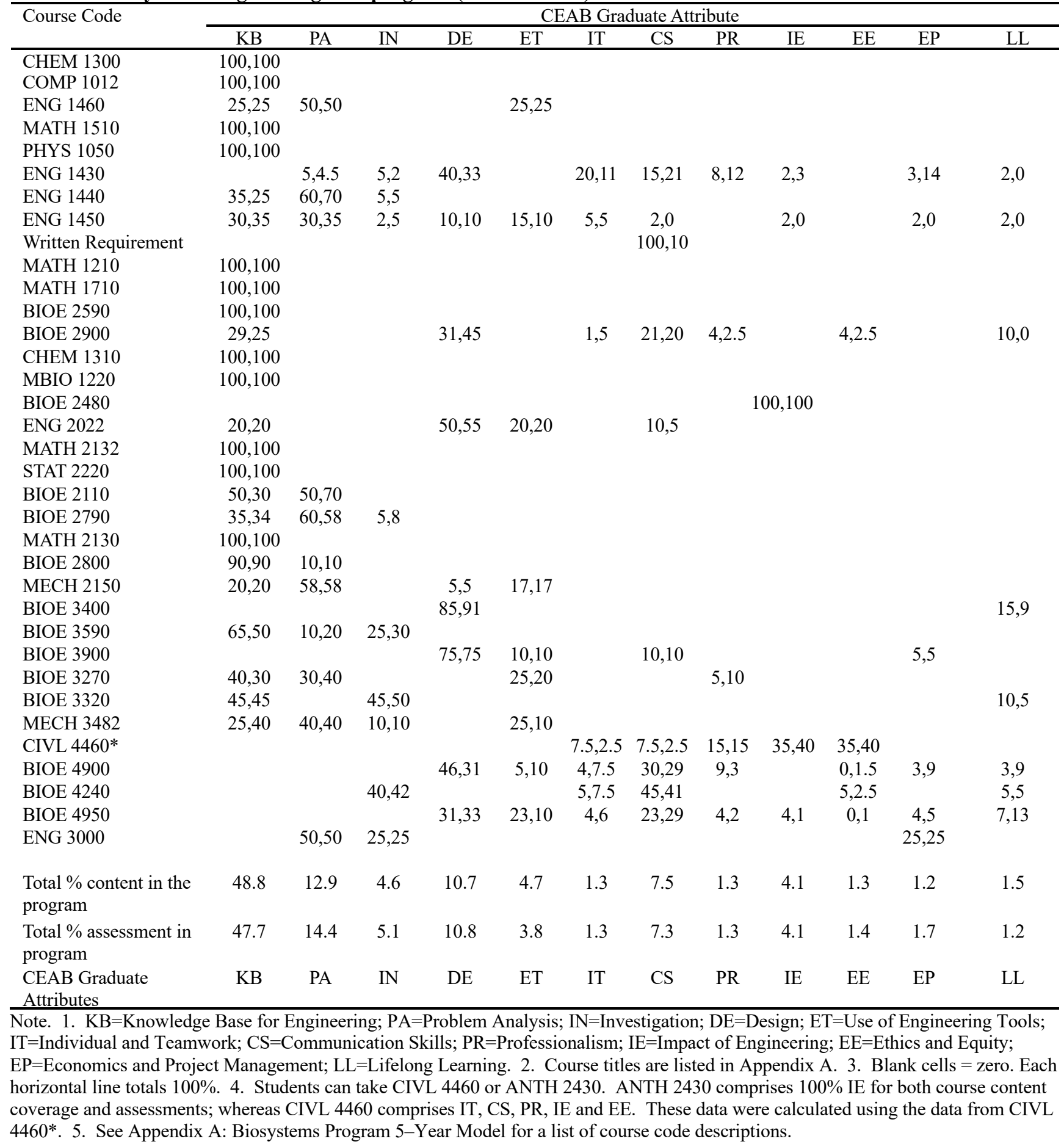


Table 5. Comparative view of the mean relative importance of CEAB graduate attributes by all stakeholders with the percentage of course content coverage and assessments in the BIOE program.

\begin{tabular}{|c|c|c|c|}
\hline $\begin{array}{l}\text { CEAB Graduate } \\
\text { Attributes }\end{array}$ & $\begin{array}{l}\text { Relative } \\
\text { Importance } \\
\text { All } \\
\text { Stakeholde } \\
\text { rs }\left(n=207^{*}\right)\end{array}$ & $\begin{array}{l}\text { BIOE \% } \\
\text { of } \\
\text { Course } \\
\text { Content } \\
\text { Coverag } \\
\text { e } \\
\end{array}$ & $\begin{array}{l}\text { BIOE \% of } \\
\text { Course } \\
\text { Assessmen } \\
\text { s }\end{array}$ \\
\hline Knowledge Base & $9.1 \%$ & $48.8 \%$ & $47.7 \%$ \\
\hline Problem Analysis & $9.0 \%$ & $12.9 \%$ & $14.4 \%$ \\
\hline Investigation & $7.2 \%$ & $4.6 \%$ & $5.1 \%$ \\
\hline Design & $7.0 \%$ & $10.7 \%$ & $10.8 \%$ \\
\hline $\begin{array}{l}\text { Engineering } \\
\text { Tools }\end{array}$ & $8.3 \%$ & $4.7 \%$ & $3.8 \%$ \\
\hline $\begin{array}{l}\text { Individual \& } \\
\text { Teamwork }\end{array}$ & $10.9 \%$ & $1.3 \%$ & $1.3 \%$ \\
\hline Communication & $10.8 \%$ & $7.5 \%$ & $7.3 \%$ \\
\hline Professionalism & $9.4 \%$ & $1.3 \%$ & $1.3 \%$ \\
\hline $\begin{array}{l}\text { Impact of } \\
\text { Engineering }\end{array}$ & $6.3 \%$ & $4.1 \%$ & $4.1 \%$ \\
\hline Ethics \& Equity & $8.8 \%$ & $1.3 \%$ & $1.4 \%$ \\
\hline $\begin{array}{l}\text { Econ. \& Project } \\
\text { Mngt. }\end{array}$ & $6.1 \%$ & $1.2 \%$ & $1.7 \%$ \\
\hline $\begin{array}{l}\text { Lifelong } \\
\text { Learning }\end{array}$ & $7.1 \%$ & $.5 \%$ & $1.2 \%$ \\
\hline
\end{tabular}

Note. Grey areas have similar expected and observed percentages. *Twelve responses were removed from the total responses $(\mathrm{N}=219)$ as these participants did not complete the entire questionnaire.

course content coverage and course assessments) are reasonably similar, and others are far apart. Although somewhat arbitrary, the percentages are identical if the highest is no more than twice as much as the lowest. This is because comparisons can be misleading when the range gets narrower, and the relative importance is already relatively narrow. When interpreting the data in this way, we can say that Problem Analysis, Investigation, Design, Communication Skills, Impact of Engineering on Society \& the Environment, and if we consider only content coverage, Use of Engineering Tools have similar expected and observed percentages (highlighted in Table 5). The other six attributes have a larger spread, with Knowledge Base for Engineering comprising almost half the Biosystems program (i.e., $48.8 \%$ content coverage and $47.7 \%$ course assessments), compared to $9.1 \%$ mean relative importance attributed by stakeholders. Following this, we see that Individual \& Teamwork, Professionalism, Ethics \& Equity, Economics \& Project Management, and Lifelong Learning have less than 2\% emphasis in the Biosystems Engineering program and are given a mean relative importance rating between $6-11 \%$. Overall, only Problem Analysis and Design have higher observed than expected performance; the rest of the graduate attributes have higher expected than observed performance. There is a broader range in the observed performance than in the expected performance.

\section{DISCUSSION}

The purpose of this study was to (1) develop a criterion measure of relative importance for each CEAB graduate attribute, and (2) assess the content validity of the Biosystems Engineering program by comparing the expected relative importance to the observed levels of content coverage and assessment, for each graduate attribute.

The graduate attributes, Problem Analysis, Investigation, Design, Communication Skills, Impact of Engineering on Society \& the Environment, and Use of Engineering Tools have similar expected (mean relative importance) and observed (content and assessment coverage in the Biosystems Engineering program) percentages in the data. Generally, the Biosystems Engineering program emphasizes the traditional skills in engineering, followed by the professional skills. In contrast, engineering stakeholders place importance on professional skills, with the most importance placed on Individual \& Teamwork and Communication Skills, the importance that is also reflected in the literature (Bodner 2002; Male 2010; Passow 2012; Passow and Passow 2017).

As expected, the gap between perceived importance and observed coverage was wider for some other graduate attributes. How closely the relative importance compares to what was observed in content coverage and assessment for a particular graduate attribute might have to do with how directly the attribute can be assessed. For most attributes whose percentages were reasonably similar, such as Problem Analysis, Investigation, Design, and Communication Skills, those attributes can be readily assessed in various forms, including exams, written assignments, presentations, and projects. In contrast, other attributes that showed greater discrepancies between the expected relative importance and observed importance, such as Professionalism, Ethics \& Equity, and Lifelong Learning, tend to be more challenging to assess directly within graded course work (Holsapple et al. 2012; Seniuk Cicek et al. 2016; Shuman et al. 2005).

Knowledge Base was a clear and somewhat surprising exception to this pattern, reflecting the degree to which a graduate attribute can be assessed directly. Knowledge Base accounts for almost half the Biosystems Engineering program, which far exceeded stakeholders' perceived importance and previous perceptions (Bodner 2002; Male 2010; Passow 2012; Passow and Passow 2017), except for Nguyen (1998). Logically, many would argue that engineering knowledge is the most fundamental competency of an engineer - indeed, the defining attribute of the profession, as without engineering knowledge, one is not an engineer. So, why then is this not reflected in our relative importance data and the literature? There are at least four possible explanations. 
The first possible explanation relates to the methodology used to determine the observed emphasis on graduate attributes in the Biosystems Engineering program. In this study, the estimate of content coverage and assessment on Knowledge Base may be higher than it should be. Of the 35 courses, 12 focused entirely (100\%) on Knowledge Base. Interestingly, 11 of those 12 courses are taught outside the Biosystems Engineering department. As mentioned earlier, the estimated proportion of assessments on each graduate attribute for these externallytaught courses was based solely on the review of the course outline. Based on the graduate attributes that appeared to be covered in the assessments for that course, it was assumed that each attribute was covered equally in terms of content coverage. All 12 courses were lower-year courses $\left(1^{\text {st }}\right.$ and $2^{\text {nd }}$ year). While lower-year courses in disciplines related to engineering (e.g., mathematics, chemistry) tend to focus more on knowledge and less on application and other higher-order objectives compared to upper-year courses, the $100 \%$ estimate for the 12 courses in this study may have been an overestimate. It may well be that in several of these 12 courses, there is some attention given to other attributes such as Problem Analysis, Design and Communication Skills.

A second possible explanation, which relates to the expected level of importance as determined through the survey of stakeholders, is that stakeholders expect that a student graduating from an accredited engineering program will already possess the required level of engineering knowledge. Therefore, stakeholders rely more heavily on the other graduate attributes to separate top engineers. The increased focus on non-technical attributes was noted by Robinson et al. (2005) in their study that explored the most important future competencies for Design engineers. While they emphasized that technical ability remains critically important, a greater focus on other attributes (e.g., personal attributes, project management skills) would help distinguish between satisfactory and outstanding performance more clearly. Thus, it is possible that the expected levels of importance presented in this paper may not be accurate.

A third possible explanation may be that the perceived relative importance of graduate attributes, as determined through the survey of stakeholders, depends on the stage of career focus. We measured the relative importance of the graduate attributes for an EIT at the beginning of their career. We argued that this is when a new engineer first engages with the CEAB graduate attributes in professional practice. We wanted to evaluate how well our program prepared engineers for practice, based on the degree to which each graduate attribute was covered in the program. However, one could argue that we train engineers for competency over their whole career, not just the beginning of their career. Thereby, the measure of an EIT at the beginning of their professional practice may not represent the most accurate portrayal of these attributes in practice.
Moreover, we construed importance as the product of frequency and criticality, which stakeholders rated separately for each CEAB graduate attribute. Conceivably, an EIT will be required to use engineering knowledge less frequently at the beginning of their career when they are still in training than an engineer who has been practicing in the field for years, at least individually (i.e., they will be overseen by a senior engineer). Thus, the frequency rating may be lower than expected. Similarly, recalling that criticality was rated in terms of the effect of errors on engineering practice, one can imagine that an EIT would be less likely to work in situations where they can make critical errors. Thus, the criticality rating would be lower. In this scenario, overall, the importance rating of engineering knowledge would be lower than expected for an engineer in practice. Further, when considering the small range in the relative importance data among all 12 graduate attributes (from $6.1 \%$ to $10.9 \%$ ), we know that stakeholders rated each graduate attribute similarly in frequency and criticality. They did not give significantly more weight to one graduate attribute over another, which may be due more to what is expected of a new EIT than a true reflection of the relative importance of the CEAB graduate attributes in engineering practice.

The fourth possible explanation is that CEAB accreditation requires program administrators to report on graduate attribute outcomes and AUs, which are based on the number of hours devoted to engineering fundamentals such as mathematics, natural sciences, engineering science, engineering design, and complementary studies. Other graduate attributes are likely being employed in each of these courses. Still, programs are constrained by CEAB requirements: they must account for a large number of AUs in each of these areas, which naturally leads to a large emphasis on attributes like Knowledge Base and the other technical skills in specific courses, and to the reduction of a formal accounting of the attributes that are not counted for AUs, which mainly, in this case, are the professional skills.

\section{Limitations}

Perhaps this study's most apparent and inherent limitation was that the results reflect only a single department within a single engineering program. As such, the findings in this study must be regarded with considerable caution.

As noted, several times above, the measures and procedures are pretty novel, both in this study and the field of engineering education. The overall intent of this study was perhaps more methodological than it was topical. We wanted to introduce a newer approach to evaluating how graduate attributes are covered in engineering programs, which can be refined in future efforts. While the measures we developed for this study were well-researched and carefully prepared, we realize, as noted in several places above, there are clear areas for improvement that we can expect to align more closely with the unique contexts in engineering education. 
The main focus of this research was to compare the expected level of importance to what is observed in the Biosystems Engineering program (which we have chosen to represent by 'proportion of instruction time' and 'percentage of grade allocation' for each graduate attribute). The data in Table 5 demonstrates that there was a reasonably close match between the expected level of importance (as indicated by the survey of stakeholders) and the proportion of instruction time (or percentage of grade allocation) observed in the Biosystems Engineering program for at least five graduate attributes; however, it also clearly shows that there is not a good match for the others. In the preceding discussion, an effort has been made to explain this discrepancy based primarily on two assumptions: 1) that the relative importance indicated by the stakeholders is correct and 2) that proportion of instruction time (or percentage of grade allocation) are appropriate indicators of the level of emphasis within an engineering program. Each of these assumptions warrants future investigation. Is it true that all 12 graduate attributes have roughly equal importance, or did the survey instrument used in this study fail to consider other factors that may contribute to the 'true' expected level of importance? Likewise, are 'proportion of instruction time' or 'percentage of grade allocation' suitable measures for the emphasis or value placed on a specific graduate attribute by an engineering department? Using the Biosystems Engineering program as an example, we offer one example to suggest that this latter assumption may not be appropriate. Table 5 indicates that less than $2 \%$ of total instruction time is devoted to formal instruction on teamwork (or assessment of teamwork skills in the Biosystems Engineering program). While there may be no reason to doubt the accuracy of these two numbers, it is also a known fact that there are five design courses in the Biosystems Engineering program (representing 11\% of the entire program) that require term-long team projects, in addition to numerous other courses that have shorterduration team projects. The Department of Biosystems Engineering emphasizes the importance of this graduate attribute by providing multiple opportunities for students to work in team settings. It does not appear that the metrics of 'proportion of instruction time' or 'percentage of grade allocation' truly reflect the emphasis on the graduate attribute of teamwork in the Biosystems Engineering program. Further research is likely required to investigate other potential metrics to reflect the level of emphasis in an engineering program more accurately.

\section{Recommendations for programs}

While the findings of this study may not justify considering course or program changes in engineering, one particular finding is perhaps a bit more deserving of consideration. The Biosystems Engineering program appears to have minimal emphasis on the professional graduate attributes such as Professionalism, Ethics \& Equity, and Lifelong Learning, which are rated comparatively higher in relative importance by all engineering stakeholder groups in this case. Engineering educators arguably have a societal responsibility to integrate 'ethical reasoning' into the engineering curriculum (Sheppard et al. 2008) and educate socially responsible engineers (Lathem et al. 2011; Terpenny et al. 2008). Research has shown that engineering practice is, by necessity, both social and technical (Cohen et al. 2014; Faulkner 2007; McGowan and Bell 2020). Practicing engineers must identify and integrate the social and technical elements of open-ended problems and evaluate their impact (Stevens et al. 2014; Swartz et al. 2019; Trevelyan 2014).

For this reason, engineering accreditation boards, including $\mathrm{CEAB}$, require university programs to demonstrate that engineering students understand the social dimensions and consequences of engineering practice (Engineers Canada 2019). This has been defined as sociotechnical thinking (Hoople and Choi-Fitzpatrick 2020; Leydens et al. 2018; Mazzurco and Daniel 2020), which is a critical skill for engineers due to the sociotechnical nature of engineering practice. Thus, there is good reason for department administrators to actively pursue opportunities to further emphasize the professional graduate attributes, potentially by integrating the teaching of professional skills with the teaching of technical skills to avoid deemphasizing one set of graduate attributes to emphasize another.

\section{Recommendations for future research}

Recommendations for future research focus on evaluating course content and assessments more accurately and making more meaningful comparisons between expected and observed coverage for each $\mathrm{CEAB}$ graduate attribute. To help improve the accuracy of measuring content coverage and assessments within a course, those should be measured directly, when possible, by asking all instructors to rate the proportion of course content coverage for each applicable attribute (i.e., in this study, the 14 (of 35) courses offered either within the Price Faculty of Engineering or in the Faculties of Arts or Sciences - where faculty did not fill out the questionnaire). For assessments, copies of blank assessments or sufficiently detailed descriptions should be obtained.

Another recommendation is to compare the relative importance ratings to the course content coverage and course assessments in the $3^{\text {rd }}$ and $4^{\text {th }}$ years of the program only. If the relative importance ratings are based on visualizing someone in the field who is expected to apply all 12 attributes, it might make more sense to compare the relative importance to the part of the program where students are expected to apply most/all of the 12 graduate attributes, rather than comparing the relative importance to the part of the program that is logically expected to strongly emphasize only one of the 12 attributes (i.e., Knowledge Base).

Finally, it is recommended that a qualitative investigation of the findings be conducted. For example, focus groups could be held with stakeholder groups to explore their understandings of the similarities and discrepancies between the expected levels of importance 
and the observed levels of performance of the graduate attributes in the Biosystems Engineering program. This will help us understand these findings more.

\section{CONCLUSION}

This study was the first among engineering programs in Canada to measure the variation in the level of importance of the $\mathrm{CEAB}$ graduate attributes and compare that against the content coverage and assessment of those attributes within an engineering program. Some of our findings emerged as expected in the sense that the relative importance was not too far away from the amount of content coverage and assessments for several graduate attributes (e.g., Design, Investigation). Other findings were less clear and somewhat surprising (i.e., the distance between the expected and observed performance of Knowledge Base). We offer that one of the main contributions of this study is the practical and relevant directions to improve the validity of assessing the CEAB graduate attributes. As far as course and program considerations, we suggest that the professional engineering competencies, including Professionalism, Ethics \& Equity, and Lifelong Learning, which are emphasized in relative importance in this study and the literature, be further emphasized in the Biosystems Engineering curriculum to ensure that students develop socio-technical thinking. Further research to improve the teaching and assessments of the professional graduate attributes is proving to be increasingly critical for the preparation of engineering students for professional practice.

\section{ACKNOWLEDGEMENTS}

The authors are grateful for the contributions of Dr. Sandra Ingram, who was the first author's doctoral supervisor at the time this research was conducted. The authors acknowledge Renato Alan Bezerra Rodrigues, Ph.D. student in the Graduate Specialization in Engineering Education in the Department of Biosystems Engineering at the University of Manitoba, for his research on sociotechnical thinking.

\section{REFERENCES}

Almarshoud, A. 2011. "Developing a rubric-based framework for measuring the ABET outcomes achieved by students of electric machinery courses. International Journal of Engineering Education 27(4): $1-8$.

Ashman, P., S. Scrutton, D. Stringer, P. Mullinger and J. Willison. 2008. Stakeholder perceptions of chemical engineering graduate attributes at the University of Adelaide. In Proceedings of the CHEMECA 2008 Conference: Towards a Sustainable Australasia, 912921. Newcastle City Hall, NSW. September 28 October 1. http://hdl.handle.net/2440/54440

Biggs, J. 2013. Constructive alignment in university teaching." HERDSA Review of Higher Education 1: 522. https://www.tru.ca/_shared/assets/Constructive _Alignment36087.pdf
Biggs, J. 1999. What the student does: Teaching for enhanced learning. Higher Education Research and Development 18 (1): 57-75.

https://doi.org/10.1080/0729436990180105

Bons, W. and A. McLay. 2003. Re-engineering engineering curricula for tomorrow's engineers. In Proceedings 14th Annual Australian Association for Engineering Education Conference, 65-76. Melbourne, Vic. September 29 - October 1. https://search.informit.org/doi/epdf/10.3316/informit.9 33697596495906

Borrego, M., and J. Bernhard. 2011. The emergence of engineering education research as an internationally connected field of inquiry. Journal of Engineering Education, 100 (1): 14-47. https://doi.org/10.1002/j.2168-9830.2011.tb00003.x

Cohen, B., J. Rossmann and K. Sanford Bernhardt. 2014. Introducing engineering as a sociotechnical process. In Proceedings American Engineering Education Association Annual Conference and Exposition Proceedings, 1-14. Indianapolis, IN. June 15-18.

Davis, D. C., S. W. Beyerlein and I. T. Davis. 2006. Deriving design course learning outcomes from a professional profile. International Journal of Engineering Education 22(3): 439-446.

Davis, D. C., K. L. Gentili, M. S. Trevisan and D. E. Calkins. 2002. Engineering design assessment processes and scoring scales for program improvement and accountability. Journal of Engineering Education 91(2): 211-221. https://doi.org/10.1002/j.21689830.2002.tb00694.x

Dew, S. K., M. Lavoie, and A. Snelgrove. 2011. An engineering accreditation management system. In Proceedings of the $2^{\text {nd }}$ Annual CEEA Conference (CEEA2011): The Evolution of Engineering Education, 1-6. St. John's, NL. June 6-8. https://ojs.library.queensu.ca/index.php/PCEEA/issue/ view/328

Driscoll, A. and S. Wood. 2007. Developing Outcomesbased Assessment for Learning-centered Education: A Faculty Introduction. Sterling, VA: Stylus.

Engineers Canada. 2019. Accreditation Criteria and Procedures.

https://engineerscanada.ca/sites/default/files/accreditat ion/Accreditation-Criteria-Procedures-2019.pdf $(2020 / 10 / 10)$.

Faulkner, W. 2007. 'Nuts and bolts and people': Gender troubled engineering identities. Social Studies of Science 37(3): 331-356.

https://doi.org/10.1177/0306312706072175

Felder, R. M. and R. Brent. 2003. Designing and teaching courses to satisfy the ABET engineering criteria. Journal of Engineering Education 92(1): 7-25. https://doi.org/10.1002/j.2168-9830.2003.tb00734.x

Frank, B. and S. Fostaty-Young. 2011. What can our students do: Year 2 of graduate attribute assessment at 
Queen's University. In Proceedings of the $2^{\text {nd }}$ Annual CEEA Conference (CEEA2011): The Evolution of Engineering Education, 1- 6. St. John's, NL. June 68. https://doi.org/10.24908/pceea.v0i0.3587

Frank, B., S. McCahan, C. K. Watts, S. Fostaty-Young, P. Ostafichuck, P. Wolf and N. Saleh. 2011. Engineering graduate attribute development (EGAD) project. In Proceedings of the $2^{\text {nd }}$ Annual CEEA Conference (CEEA2011): The Evolution of Engineering Education, 1-3. St. John's, NL. June 6-8.

https://doi.org/10.24908/pceea.v0i0.3566

Fredericks Volkwein, J., L. R. Lattuca, P. T. Terenzini, L. C. Strauss and J. Sukhbaatar. 2004. Engineering change: A study of the impact of EC2000. International Journal of Engineering Education 20(3): 318-328.

Gliner, J. A., G. A. Morgan and N. L. Leech. 2009. Research in Applied Settings, $2^{\text {nd }}$ edition. New York, NY: Routledge.

Heinricher, A. C., J. E. Miller, L. Schachterle, N. K. Kildahl, V. Bluemel and V. Crawford. 2002. Undergraduate learning portfolios for institutional assessment. Journal of Engineering Education 91(2): 249-253. https://doi.org/10.1002/j.21689830.2002.tb00699.x

Holsapple, M., D. Carpenter, J. Sutkus, C. Finelli and T. Harding. 2012. Framing faculty and student discrepancies in engineering ethics delivery. Journal of Engineering Education 101(2): 169-186. https://doi.org/10.1002/j.2168-9830.2012.tb00047.x

Hoople G. D. and A. Choi-Fitzpatrick. 2020. Drones For Good: How To Bring Sociotechnical Thinking Into The Classroom. San Rafael, CA: Morgan and Claypool. https://doi.org/10.2200/S00984ED1V01Y202001ETS0 24

International Engineering Alliance. 2014. 25 years Washington Accord. 1989-2014: Celebrating international engineering standards and recognition. https://www.ieagreements.org/accords/washington/ (2020/11/22).

Jonsson, A. and G. Svingby. 2007. The use of scoring rubrics: reliability, validity and educational consequences. Educational Research Review 2: 130144. https://doi.org/10.1016/j.edurev.2007.05.002

Lathem, S., M. Neumann and N. Hayden. 2011. The socially responsible engineer: Assessing student attitudes of roles and responsibilities. Journal of Engineering Education 100(3): 444-471. https://doi.org/10.1002/j.2168-9830.2011.tb00022.x

Leydens, J. A., K. Johnson, S. Claussen, J. Blacklock, B. M. Moskal and O. Cordova. 2018. Measuring change over time in sociotechnical thinking: A survey/validation model for sociotechnical habits of mind. In Proceedings American Engineering Education Association Annual Conference and
Exposition Proceedings, 1-22. Salt Lake City, UT. June 24-27.

Male, S. 2010. Generic engineering competencies: A review and modelling approach. Education Research and Perspectives 37(1): $25-51$.

Male, S. A., M. B. Bush and E. S. Chapman. 2010. Perceptions of competency deficiencies in engineering graduates. Australasian Journal of Engineering Education 16(1): 55-68. https://doi.org/10.1080/22054952.2010.11464039

Male, S. A., M. B. Bush and E. S. Chapman. 2011a. An Australian study of generic competencies required by engineers. European Journal of Engineering Education 36(2): 151-163. https://doi.org/10.1080/03043797.2011.569703

Male, S. A., M. B. Bush and E. S. Chapman. 2011b. Understanding generic engineering competencies. Australasian Journal of Engineering Education 17(3), 147-156. https://doi.org/10.1080/22054952.2011.11464064

Mazzurco, A. and S. Daniel. 2020. Socio-technical thinking of students and practitioners in the context of humanitarian engineering. Journal of Engineering Education 109(2): 243-261. https://doi.org/10.1002/jee.20307

McCahan, S., L. Romkey and G. Allen. 2011. Development of the graduate attribute quality assurance process at the University of Toronto. In Proceedings of the $2^{\text {nd }}$ Annual CEEA Conference (CEEA2011): The Evolution of Engineering Education, 1-6. St. John's, NL. June 6-8. https://doi.org/10.24908/pceea.v0i0.3590

McGourty, J., M. Besterfield-Sacre and L. Shuman. 1999. ABET's eleven student learning outcomes (A-K): Have we considered the implications? In Proceedings American Engineering Education Association Annual Conference and Exposition Proceedings, 1-10. Charlotte, NC. June 20-23. https://peer.asee.org/abets-eleven-student-learning-outcomes-a-k-have-weconsidered-the-implications

McGowan, V. C. and P. Bell. 2020. Engineering education as the development of critical sociotechnical literacy. Science and Education 29(4): 1-25. https://doi.org/10.1007/s11191-020-00151-5

Moskal, B. M. 2008. "Using Assessment Results for Improving Student Learning." In Designing Better Engineering Education Through Assessment, edited by J. E. Spurlin, S. A. Rajala, and J. P. Lavelle, 117-148. Sterling: Stylus.

Nair, C.S., A. Patil, and P. Mertova. 2009. Re-engineering graduate skills - a case study. European Journal of Engineering Education 34(2), 131-139. https://doi.org/10.1080/03043790902829281

NEERC (National Engineering Education Research Colloquies). 2006. Special report: The research agenda 
for the new discipline of engineering education. Journal of Engineering Education 95(4) 259-261. https://doi.org/10.1002/j.2168-9830.2006.tb00899.x

Nguyen, D. Q. 1998. The essential skills and attributes of an engineer: A comparative study of academics, industry personnel and engineering students. Global Journal of Engineering Education 2(1): 65-75. http://citeseerx.ist.psu.edu/viewdoc/download?doi=10. 1.1.124.1502\&rep=rep1\&type=pdf

Olds, B., B. Moskal and R. L. Miller. 2005. Assessment in engineering education: Evolution, approaches and future collaborations. Journal of Engineering Education 94(1): 13-25.

https://doi.org/10.1002/j.2168-9830.2005.tb00826.x

Oliver, B. 2013. Graduate attributes as a focus for institution-wide curriculum renewal: Innovations and challenges. Higher Education Research and Development 32(3), 450-463.

https://doi.org/10.1080/07294360.2012.682052

Passow, H. 2012. Which ABET competencies do engineering graduates find most important in their work? Journal of Engineering Education 101(1): 95$118 . \quad$ https://doi.org/10.1002/j.21689830.2012.tb00043.x

Passow, H. J. and C. H. Passow. 2017. What competencies should undergraduate engineering programs emphasize? A systematic review. Journal of Engineering Education 106(3): 475-526. https://doi.org/10.1002/jee.20171

Pons, D. 2016. Relative importance of professional practice and engineering management competencies. European Journal of Engineering Education 41(5): 530-547. https://doi.org/10.1080/03043797.2015.1095164

Popp, A. B., D. C. Levy and S. Barrie. 2012. Rationalizing relationships between the various sets of learning outcomes as a data driven mapping strategy. International Journal of Engineering Education 28(4): 966-981.

Prados, J. W., G. D. Peterson and L. R. Lattuca. 2005. Quality assurance of engineering education through accreditation: The Impact of engineering criteria 2000 and its global influence. Journal of Engineering Education 94(1): 165-184.

https://doi.org/10.1002/j.2168-9830.2005.tb00836.x

Renaud, R. 2019. Assessing the content validity of a clinical competency exam in nursing. University of Manitoba. (Manuscript in preparation).

Ro, H. K., D. Merson, L. R. Lattuca and P. T. Terenzini. 2015. Validity of the contextual competence scale for engineering students. Journal of Engineering Education 104(1): 35-54.

https://doi.org/10.1002/jee.20062
Robinson, M. A., P. R. Sparrow, C. Clegg and K. Birdi. 2005. Design engineering competencies: Future requirements and predicted changes in the forthcoming decade. Design Studies 26 (2005): 123-153.

https://doi.org/10.1016/j.destud.2004.09.004

Rogers, G. 2000. EC2000 and measurement: How much precision is enough? Journal of Engineering Education 89(2): 161-166. https://doi.org/10.1002/j.21689830.2000.tb00510.x

Scott, G. and K.W. Yates. 2002. Using successful graduates to improve the quality of undergraduate engineering programmes. European Journal of Engineering Education 27(4): 363-378. https://doi.org/10.1080/03043790210166666

Seniuk Cicek, J., S. Ingram and M. Friesen. 2016. On becoming an engineer: The essential role of lifelong learning competencies. In Proceedings of the American Society for Engineering Education $123^{\text {rd }}$ Annual Conference and Exposition: Jazzed about Engineering Education, 1-17. New Orleans, LA. June 26-29.

Seniuk Cicek, J., S. Ingram, D. Mann and R. D. Renaud. 2017a. Investigating the relative importance of the CEAB graduate attributes: Study design and initial findings. In Proceedings of the Canadian Engineering Education Association Conference: Innovation and Diversity in Engineering Education (CEEA-ACEG), 19. Toronto, ON. June 4-7.

https://doi.org/10.24908/pceea.v0i0.10404

Seniuk Cicek, J., D. Mann and S. Ingram. 2017b. Validating and implementing engineering graduate attribute rubrics in a biosystems engineering curriculum. In Proceedings of the $47^{\text {th }}$ Annual Frontiers in Education (FIE) Conference, 1-6. Indianapolis, IN. October 18-21. https://doi.org/10.1109/FIE.2017.8190632

Seniuk Cicek, J., R. D. Renaud, S. Ingram and D. Mann. 2018. Determining the content validity of a biosystems engineering program. In Proceedings of the Canadian Engineering Education Association Conference: Building Foundations for Student Success (CEEAACEG), 1-8. Vancouver, BC. June 4-6.

https://doi.org/10.24908/pceea.v0i0.13007

Seniuk Cicek, J. and R. D. Renaud. 2019. "Determining the dependencies of engineering competencies for engineering practice: An exploratory case study." In Proceedings of the American Society for Engineering Education 126 $6^{\text {th }}$ Annual Conference and Exposition: Charged up for the Next 125 Years, 1-18. Tampa, FL. June 16-19.

Sheppard, S. D., J. W. Pellegrino and B. M. Olds. 2008. On becoming a $21^{\text {st }}$ century engineer. Journal of Engineering Education 97(3): 231 - 234.

https://doi.org/10.1002/j.2168-9830.2008.tb00972.x 
Shuman, L. J., M. Besterfield-Sacre and J. McGourty. 2005. The ABET 'Professional Skills' - Can they be taught? Can they be assessed? Journal of Engineering Education 94 (1): 41-55.

https://doi.org/10.1002/j.2168-9830.2005.tb00828.x

Soundarajan, N. 2002. Preparing for accreditation under EC2000: An experience report. Journal of Engineering Education 91(1): 117-123. https://doi.org/10.1002/j.2168-9830.2002.tb00680.x

Stevens, R., A. Johri and K. O’Connor. 2014. Professional engineering work. In Cambridge Handbook of Engineering Education Research, eds. A. Johri and B. M. Olds, 119-138. Cambridge, UK: Cambridge University Press. https://doi.org/10.1017/CBO9781139013451.010

Stutsky, B. J., M. Singer and R. Renaud. 2012. Determining the weighting and relative importance of CanMEDS roles and competencies. BMC Research Notes 5(354): 1-7 https://doi.org/10.1186/1756-0500-5-354

Sullivan, M. and Brennan, R. 2018. Graduate attribute assessment practice in Canadian engineering programs. In Proceedings 2018 Canadian Engineering Education Association (CEEA-ACEG18) Conference, 1-6. University of British Columbia, BC. June 3-6.

Swartz, M., J. Leydens, J. Walter and K. Johnson. 2019. Is sociotechnical thinking important in engineering education?: Survey perceptions of male and female undergraduates. In Proceedings of the American Society for Engineering Education $126^{\text {th }}$ Annual Conference and Exposition: Charged up for the Next 125 Years, 1-29. Tampa, FL. June 16-19.

Terpenny, J., R. Goff, V. Lohani, J. Mullin and J. Lo. 2008. Preparing globally and socially-conscious engineers: International and human-centred design projects and activities in the first year. International Journal of Engineering Education 24: 409-419.

Trevelyan, J. P. 2014. The Making of an Expert Engineer: How to Have a Wonderful Career Creating a Better World and Spending Lots of Money Belonging to Other People. Leiden, The Netherlands: CRC Press, Taylor \& Francis Group. https://doi.org/10.1201/b17434

Wolf, P. and W. Stiver. 2011. Graduate attributes: Intentional mapping and assessment portfolios. In Proceedings of the $2^{\text {nd }}$ Annual CEEA Conference (CEEA2011): The Evolution of Engineering Education, 1-4. St. John's, NL. June 6-8.

https://doi.org/10.24908/pceea.v0i0.3572

\section{LIST OF SYMBOLS}

ABET Accreditation Board for Engineering and Technology

AU Accreditation Unit

CEAB Canadian Engineering Accreditation Board

EIT Engineer-in-training

ENREB Education and Nursing Research Ethics Board

NEERC National Engineering Education Research Colloquies

\section{APPENDICES}

\section{Appendix A: Biosystems Program 5-Year Model}

Year 1

1

2

3

Complementary Studies Elective 1 CHEM 1300 Structure and Modelling in Chemistry

COMP 1012 Computer Programming for Science and Engineers

4 ENG 1460 Introduction to Thermal Sciences

5 MATH 1510 Applied Calculus 1

6 PHYS 1050 Physics 1: Mechanics

7 ENG 1430 Design in Engineering

8 ENG 1440 Introduction to Statics

9 ENG 1450 Introduction to Electrical and Computer Engineering

10 Written Requirement

11 MATH 1210 Techniques of Classical and Linear Algebra

12 MATH 1710 Applied Calculus 2

Year 2

13 BIOE 2590 Biology for Engineers

14 BIOE 2900 Biosystems Engineering Design 1

15 CHEM 1310 University Chemistry 1

16 MBIO 1220 Essentials of Microbiology

17 BIOE 2480 Impact of Engineering on the Environment

18 ENG 2022 Engineering CAD Technologies for Biosystems

MATH 2132 Engineering Mathematical Analysis 2 STAT 2220 Contemporary Statistics for Engineers

Complementary Studies Elective 2

BIOE 2110 Transport Phenomenon

BIOE 2790 Fluid Mechanics

MATH 2130 Engineering Mathematical Analysis 1

Science Elective 1 (BIOL 1410 or SOIL 4060)

BIOE 2800 Solid Mechanics

MECH 2150 Mechanical Engineering Modeling and Numerical Methods

28 Science Elective 2 (BIOL 1412 or BIOE 2600) Elective Slot

Year 4

BIOE 3400 Design of Structural Components in Machines

30 BIOE 3590 Mechanics of Materials in Biosystems

31 BIOE 3900 Biosystems Engineering Design 2

32 Complementary Studies Elective 3

33 BIOE 3270 Instrumentation and Measurement for Biosystems

34 BIOE 3320 Engineering Properties of Biological Materials

35 MECH 3482 Kinematics and Dynamics

36 ANTH 2430 Ecology, Technology and Society (or CIVL 4460 Technology, Society \& the Future)

37 BIOE Design Elective 1

Year 5

38 BIOE 4900 Biosystems Engineering Design 3

39 BIOE 4240 Graduation Project

$40 \quad$ BIOE Design Elective 2

41 Free Elective 1

42 BIOE 4950 Biosystems Engineering Design 4

43 ENG 3000 Engineering Economics

44 BIOE Design Elective 3

$45 \quad$ Free Elective 2 
1 A knowledge base for engineering: Demonstrated competence in university level mathematics, natural sciences, engineering fundamentals, and specialized engineering knowledge appropriate to the program.

2 Problem analysis: An ability to use appropriate knowledge and skills to identify, formulate, analyze, and solve complex engineering problems in order to reach substantiated conclusions.

3 Investigation: An ability to conduct investigations of complex problems by methods that include appropriate experiments, analysis and interpretation of data and synthesis of information in order to reach valid conclusions.

4 Design: An ability to design solutions for complex, open-ended engineering problems and to design systems, components or processes that meet specified needs with appropriate attention to health and safety risks, applicable standards, and economic, environmental, cultural and societal considerations.

5 Use of engineering tools: An ability to create, select, apply, adapt, and extend appropriate techniques, resources, and modern engineering tools to a range of engineering activities, from simple to complex, with an understanding of the associated limitations.

6 Individual and team work: An ability to work effectively as a member and leader in teams, preferably in a multi-disciplinary setting.

7 Communication skills: An ability to communicate complex engineering concepts within the profession and with society at large. Such ability includes reading, writing, speaking and listening, and the ability to comprehend and write effective reports and design documentation, and to give and effectively respond to clear instructions.

8 Professionalism: An understanding of the roles and responsibilities of the professional engineer in society, especially the primary role of protection of the public and the public interest.

9 Impact of engineering on society and the environment: An ability to analyze social and environmental aspects of engineering activities. Such ability includes an understanding of the interactions that engineering has with the economic, social, health, safety, legal, and cultural aspects of sustainable design and development and environmental stewardship.

10 Ethics and equity: An ability to apply professional ethics, accountability, and equity.

11 Economics and project management: An ability to appropriately incorporate economics and business practices including project, risk and change management into the practice of engineering and to understand their limitations.

12 Lifelong learning: An ability to identify and to address their own educational needs in a changing world in ways sufficient to maintain their competence and to allow them to contribute to the advancement of knowledge. 
Appendix C: Teaching Faculty Course Content Questionnaire

Example for BIOE 2790. (Note: Questionnaire was created for each individual course in the program, based on the graduate attributes that were identified for accreditation purposes.)

Teaching Faculty Course Content Questionnaire

1. Based on the Graduate Attribute table that was developed for BIOE 2790, these CEAB graduate attributes are taught and/or assessed in your course:

\begin{tabular}{|c|c|c|}
\hline Graduate Attribute & Weight & $\begin{array}{l}\text { Level } \\
\mathrm{I} / \mathrm{D} / \mathrm{A}\end{array}$ \\
\hline A Knowledge Base for Engineering & & I \\
\hline Problem Analysis & & I \\
\hline Investigation & & I \\
\hline
\end{tabular}

Is the list correct? Yes No

(If no, please cross out any graduate attributes that are listed but aren't associated with your course and/or add any graduate attributes that are missing.)

2. In your judgment, when you consider the content covered in this course (i.e., through teaching, readings, homework, and other methods of course content delivery), approximately what percentage of the content is allocated for each of the graduate attributes listed in question 1 ?

\begin{tabular}{ll}
\hline Graduate Attribute & $\begin{array}{l}\text { Percentage of } \\
\text { content coverage } \\
\text { (where total does not exceed 100\%) }\end{array}$ \\
\hline
\end{tabular}

Total:

$</=100 \%$

3. In your judgment, when you consider all of the assessment tools used in this course (i.e., any work that students will receive a mark/grade for, including lab reports, homework, tutorials, quizzes, tests, exams, projects, etc.), approximately what percentage of these assessments is allotted to each of the graduate attributes listed in question 1 ?

Graduate Attribute

Percentage of assessments

(where total does not exceed 100\%)

Total:

$</=100 \%$ 